\title{
RESULTS OF DAIRY FARMS IN POLAND COMPARED TO THE LARGEST MILK PRODUCERS IN THE EUROPEAN UNION
}

\begin{abstract}
The article presents economic results and production efficiency in milk production farms in the six EU countries, which are the largest producers in the EU (i.e. Germany, France, Great Britain, Poland, the Netherlands and Italy). The analysis used FADN EU average data for 2010-2013. The results of Polish farms in 2014-2015 were also evaluated, the data collected in the Polish FADN system was used. The measure of the economic situation of farms was net added value and farm income. Production efficiency was assessed using the productivity index of inputs and fixed assets, profitability index of production and the relation of costs to value production and to farm income without subsidies. The investment activity, the level of debt and the wealth of the farm and its use were also analysed.

In terms of production efficiency dairy farms in Italy and Poland stand out. This is shown by high profitability of production, relatively low costs, production of 100 euro value of production and 100 euro of income without subsidies and high productivity of inputs. The results were influenced by low level of debt of farms, as a result lower costs. In the case of Italian farms, liabilities financed $1.1 \%$ of the value of their assets, in the case of Polish farms $-5.7 \%$, while $42.7 \%$ for French farms. This means that French farms were characterized by high financial risks related to running a production activity. Polish FADN data indicate a deterioration of the income situation of dairy farms in Poland in 2015 (i.e. after the abolition of milk quotas) compared to 2014. Income without subsidies decreased by $50.7 \%$ and income with subsidies - by $15.4 \%$. Due to lower revenues (e.g. due to the fall in the price of milk), the economic efficiency of production has also deteriorated.
\end{abstract}


Keywords: milk production, dairy farms, farm income, subsidies, production efficiency, parity income.

JEL codes: D33, Q12, Q14.

\section{Introduction}

In Poland, the share of cow's milk in the commodity structure of agricultural production is the largest, in 2015 it was $16.5 \%$, while in the livestock commodity production $-28.1 \%$ (GUS, 2016). For many farms, the milk production is the most important source of income, and the situation and development potential of these farms affect the whole of agriculture. In Poland, for many years we have observed the processes of concentration and intensification of the milk production. The number of farms keeping cows and the number of cows decrease, and the increase in the milk production is associated with the increased milk yield of cows.

The dairy sector is also an important sector in the European Union (EU). Major milk producers are Germany, France, Great Britain, Poland, the Netherlands and Italy, which together produce nearly $70 \%$ of milk produced in the EU. In 2014, the milk production in the EU was 159.8 million tonnes, of which milk produced in the EU-15 countries ${ }^{1}$ amounted to $82 \%$ and in the EU-N13 countries $^{2}-18 \%$. The largest share of the EU milk production is that of Germany about $20 \%$. The milk production volume in the EU is very diverse, there are many countries in which it does not exceed 1 million tonnes and those such as Germany or France, where the production in 2014 was about 32 and 26 million tonnes, respectively (European Commission, 2017). Therefore, in the EU only several countries with the high production potential have a decisive influence on the market situation. The largest milk producers are mostly the countries belonging to the EU-15. Among the countries that joined the EU after 2004 (EU-N13), only Poland is included in this group. In the EU milk production, Poland is ranked fourth, with the share of more than $8 \%$.

According to the data of the European Commission (European Commission, 2016), in 2013 in the EU-15 one farm had, on average, 55 dairy cows with the milk yield of 7,264 kg/cow, while in the EU-N13 - only 9 cows with the milk yield of $5,036 \mathrm{~kg} / \mathrm{cow}$. Therefore, the milk production volume per farm, on average, in the EU-15 countries was 8.7 times higher (401 in relation to 46 tonnes). This data indicates a wide variety of dairy farms in the EU-28.

\footnotetext{
${ }^{1}$ EU-15 - the countries which formed the EU before the accession of new members in 2004. They are: Austria, Belgium, Denmark, Finland, France, Greece, Spain, the Netherlands, Ireland, Luxembourg, Germany, Portugal, Sweden, Great Britain, Italy.

${ }^{2}$ EU-N13 - the countries which joined the EU in 2004 and in the following years. They are: Bulgaria, Croatia, Cyprus, the Czech Republic, Estonia, Lithuania, Latvia, Malta, Poland, Romania, Slovakia, Slovenia, Hungary.
} 
These differences are underpinned by the natural potential of farms, but of importance is also the social, economic and regulatory context. It is mostly about the different policy of the Member States as regards management of milk quotas, which in the past could have an impact on the level of the restructuring of the countries.

The development of the milk production in recent years has been associated with the increased milk yield of cows. Probable is further "industrialisation" in the dairy sector. The development of animal genetics and improvement of the way of their nutrition may result in an increase in the milk production from 2 to $3 \%$ per cow a year (Von Keyserlingk, Rushen, de Passille and Weary, 2009). From the information published by the EC (European Commission, 2015) it results that in the next few years (until 2025) we should expect the increased milk yield of cows, but these changes will have a different intensity in the EU-15 and EU-N13 countries. The number of cows will likely decrease, however, this does not reduce the milk production in the EU. Just the opposite, its volume will continue to increase due to higher milk yield of cows.

\section{Objective of the studies, data sources and methodology}

The objective of the studies was to assess the economic results and efficiency of production on the farms focused on the milk production in Poland when compared to the similar farms in the selected European Union countries. Those studies were complemented by an assessment of the income situation of the Polish farms after the abolition of milk quotas.

The subject of the studies were the farms specialising in dairy cattle (type TF 14) in six countries, which are the largest milk producers in the EU, i.e. Germany, France, Great Britain, Poland, the Netherlands and Italy. Analysis used the most up-to-date data available at the time of analyses, i.e. for 2010-2013, collected and processed in the EU FADN system (Farm Accountancy..., 2017). The selection criterion for those countries was the annual milk production exceeding 10 million tonnes (Fig. 1). 


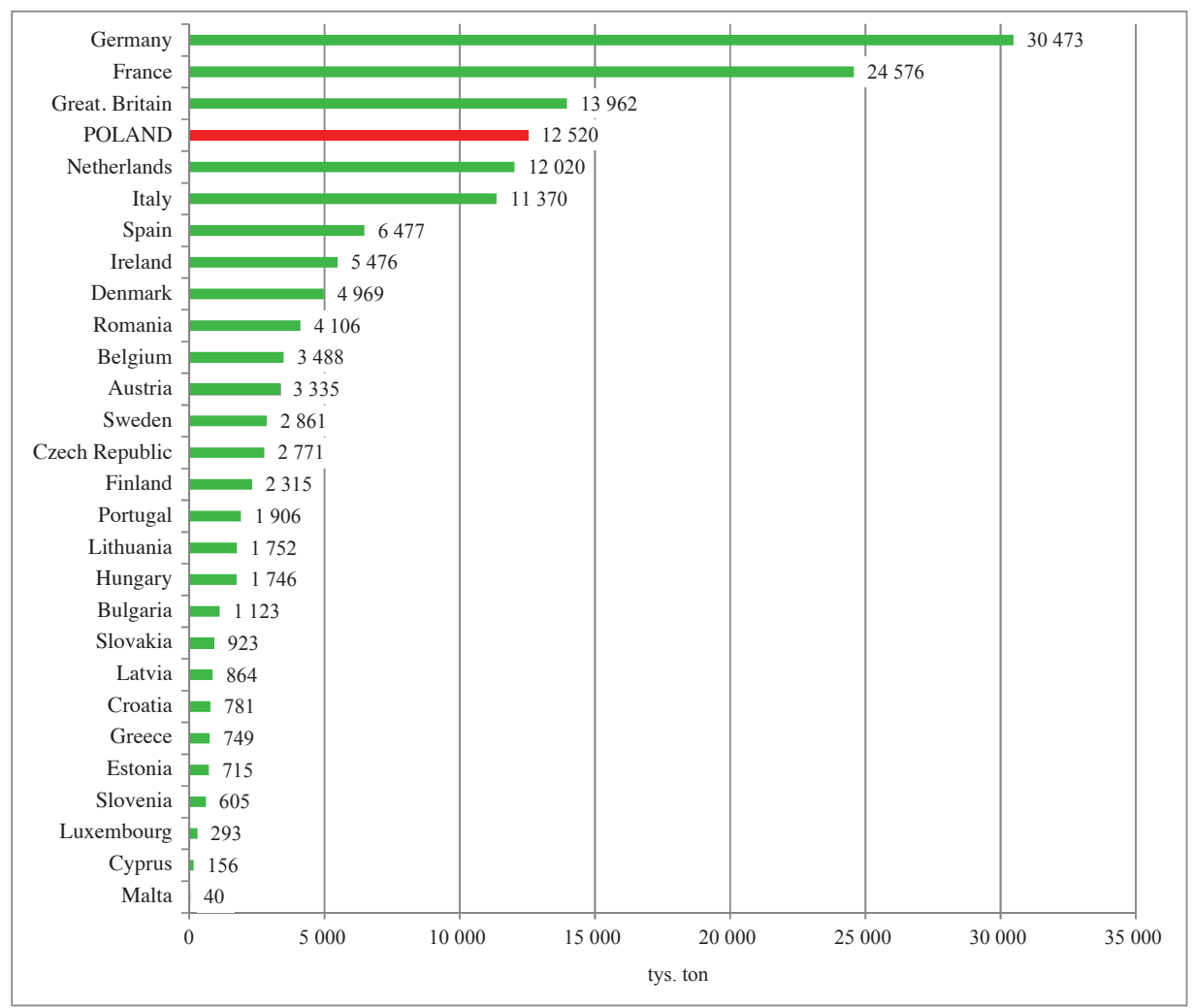

Fig. 1. Production of cow's milk in the EU countries, on average, in the years 2010-2013. Source: own study based on the European Commission (2017).

The results of the farms in a tabular form were presented on average in the adopted study period (2010-2013). The studies used a horizontal analysis, comparing the parameters describing the farms in individual countries. Analysis covered the production potential, i.e. utilised agricultural area (UAA), labour resources expressed by the number of full-time employees (AWU3) and total assets ${ }^{4}$. The structure of fixed assets and production organisation on the farms were also

\footnotetext{
${ }^{3}$ Total labour input (AWU) - total labour input as part of the farm's operating activity (in Poland, it is 2,120 hours), expressed in work units, i.e. full-time employees (Floriańczyk, Mańko, Osuch and Płonka, 2014).

${ }^{4}$ Farm assets (means of production) are divided into fixed and current assets. Fixed assets include: agricultural land, permanent crops and production quotas, farm buildings and their permanent equipment, machinery, equipment and means of transport and female animals from the breeding stock. Current assets include: value of all production animals (except for the animals from the breeding stock), stocks of agricultural products, value of standing crops, shares of the farm in agricultural units, short-term receivables and cash in hand and on a bank account in an amount necessary for the current functioning of the farm (Floriańczyk, Mańko, Osuch and Płonka, 2014).
} 
examined. For the assessment of the economic situation of the farms, net value added and farm income were used. Net value added is a useful category to analyse the economic results in a situation of different structure of ownership of production factors on the farms (Goraj and Mańko, 2004). The assessment covered the economic land and labour productivity, expressed in the studies as net value added per, respectively, 1 ha of utilised agricultural area and 1 AWU. Net value added was reduced by subsidies to the farm's operating activity. The rationale was to examine the economic impact of the production processes and the efficiency of using production factors without the impact of external support. An indicator of the assessment of the results was also farm income, but the studies also covered the production value and costs. Due to significant differences in employment of farmer's family members, analysis covered the income value per 1 family member fully employed full-time (FWU $)^{5}$. The production efficiency was assessed using:

- production profitability index (ratio of farm income without subsidies ${ }^{6}$ to production value ${ }^{7}$ ),

- ratio of total $\operatorname{costs}^{8}$ to the production value (total costs of producing EUR 100 of production),

- ratio of total costs to farm income without subsidies (total costs of achieving EUR 100 of farm income without subsidies),

- current assets productivity index (ratio of production value to intermediate consumption),

- fixed capital input productivity index (ratio of the production value to depreciation of fixed assets).

The productivity indices express the farm efficiency in transforming inputs of production factors into outputs. In addition, they reflect both the technical and economic aspect of the economic activity (Coelli, Prasada Rao, O'Donnell and Battese, 2005). On the farms, the productivity assessment and analysis is a an efficient management tool and, in particular, it allows to assess the results achieved by the farm when compared to other entities, particularly with the same line of production. Based on literature, it can be concluded that there is no one universal

\footnotetext{
${ }^{5}$ Unpaid labour input (FWU) - labour input within the farm's operating activity of unpaid persons, mainly family members, expressed in work units, i.e. fully employed family members (Floriańczyk, Mańko, Osuch and Płonka, 2014).

${ }^{6}$ Family farm income less subsidies to operating activity.

${ }^{7}$ Total production value includes the value of crop, livestock and other production expressed in market prices (Floriańczyk, Mańko, Osuch and Płonka, 2014).

${ }^{8}$ Total costs inclue: direct costs (of crop, livestock and other production) and indirect costs. Indirect costs include: overheads (e.g. cost of current maintenance of the buildings and machinery, energy, services, transport insurance and other, depreciation of fixed assets and cost of external factors (remuneration of paid workers, rents for rented land and buildings, and interest on liabilities). The total of direct costs and overheads related to the operating activity (but not recognised as direct costs of operating activity) is called intermediate consumption. According to the FADN system, taxes related to the functioning of the farms are not included in total costs (Floriańczyk, Mańko, Osuch and Płonka, 2014).
} 
indicator of productivity. Sets of productivity indices proposed by various authors are different (Morse, 1994; Lis (ed.), 1999; Coelli, Prasada Rao, O'Donnell and Battese, 2005; Poczta, Średzińska and Pawlak, 2008; Kosieradzka, 2012). The most commonly analysed are partial productivity indices, describing the use of individual types of resources. The studies - using the variables available in the EU FADN database - used the indices illustrating the productivity of current inputs (measured by the value of intermediate consumption) and fixed capital (measured by the value depreciation of fixed assets). The assessment also included dependence of the farms on subsidies to the operating activity. Therefore, the impact of the CAP on the economic effects of the farms was determined.

Bearing in mind the assessment of the situation of the analysed farms and determination of the prospects for their functioning in the future, analysis covered the investment activity, assets of the farms and their use as well as the debt level. The studies used the following indices:

\begin{tabular}{|c|c|c|}
\hline $\begin{array}{l}\text { Reproduction rate of } \\
\text { fixed assets (\%) }\end{array}$ & $=$ & $\begin{array}{l}\text { net investments } \\
\text { fixed assets }\end{array}$ \\
\hline $\begin{array}{l}\text { Farm debt } \\
\text { level }(\%)\end{array}$ & $=$ & $\frac{\text { total liabilities }}{\text { fixed assets }}$ \\
\hline $\begin{array}{l}\text { Debt structure } \\
\text { index }(\%)\end{array}$ & $=$ & $\begin{array}{c}\text { long-term liabilities } \\
\text { total liabilities }\end{array}$ \\
\hline $\begin{array}{l}\text { Asset immobilisation } \\
\text { ratio (times) }\end{array}$ & $=$ & $\frac{\text { fixed assets (without land) }}{\text { current assets }}$ \\
\hline
\end{tabular}

The reproduction rate of fixed assets is reflected by the ratio (in percentage terms) of net investment ${ }^{9}$ to fixed assets. This index shows the degree of replacement of owned assets. Therefore, it informs whether in the farms there is simple, expanded or reduced reproduction ${ }^{10}$. If the value of the index ranges from -1.0 to $1.0 \%$, then the analysed entities are characterised by simple reproduction, if it is above $1.0 \%$ - by expanded reproduction, and when it is below $-1.0 \%$ - by reduced reproduction (Józwiak, 2003).

\footnotetext{
${ }^{9}$ Net investments is the value of gross investments less depreciation (calculated for the fiscal year). Gross investments is the value of purchased and produced fixed assets in the given fiscal year, reduced by the value of assets which were sold and provided free of charge, and then increased by the difference in the value of the breeding stock ( Floriańczyk, Mańko, Osuch and Płonka, 2014).

${ }^{10}$ In the case of simple reproduction, only this part of fixed assets is replaced which was consumed during the production cycle, this means that gross investment (excluding the cost of purchase of land) shall cover only depreciation. In the case of expanded reproduction, investments cover depreciation, and increase the resources of fixed assets on the farm. On the other hand, in the case of reduced reproduction, fixed assets consumed in the production process are not completely replaced (Encyclopedia..., 1984).
} 
The farm debt level shows what part of the value of farms' assets accounts for liabilities, therefore, it points to the financial risk related to the production activity. The higher is the value of this index, the higher is the financial risk. On individual farms, the value of this index should not exceed 50\% (Goraj and Kulawik, 1995; Zieliński, 2009).

The debt structure index expresses the percentage share of the value of long-term liabilities in total liabilities. The higher value of this index means the greater financial stability of the farms (Nowak, 2008).

The asset immobilisation ratio reflects the level of immobilising resources involved in the farm's production activity. The higher is the value of this index, the longer is the period of immobilising assets. If the index exceeds 1.0, this means that the value of fixed assets exceeds the value of current assets. Then, the farms are less flexible in carrying out restructuring changes and adapting to market transformations (Nowak, 2008).

The subject of the studies were also the farms focused on milk production (type - dairy cows) in Poland in 2014-2015. The studies used the data collected and processed in the Polish FADN. It was not possible to carry out such studies using the EU FADN data, as the results in the EU database are provided with some delay. In assessing the economic situation of the farms, we examined the possibility of achieving income which will cover the costs of labour of the farmer and his family members at the parity level, i.e. at the level achieved by those employed in the national economy (parity income corresponds to the average net salary in the national economy).

\section{The results of farms focused on milk production in Poland against the background of similar farms in the selected EU countries, on average, in 2010-2013}

Production potential of the farms. The production potential of a farm is affected by a group of which cause an increase in production in the cause and effect chain. According to Woś (ed.) (1996), resources of the farms intentionally involved in the production process and actively participating in it, are called production factors. This term includes labour (human resources), land and capital. In quantitative terms, these factors determine the level of employment, area of land and the value of current and fixed production assets. Thus, it may be assumed that the production capacity of farms are shaped by external conditions and by conditions and resources of factors on the farm (Mańko, 2015). 
Table 1

Production potential of farms focused on milk production in the selected EU countries, on average, in 2010-2013

\begin{tabular}{|c|c|c|c|c|c|c|c|}
\hline Specification & & Germany & France & $\begin{array}{c}\text { Great } \\
\text { Britain }\end{array}$ & Poland & Netherlands & Italy \\
\hline $\begin{array}{l}\text { Economic size } \\
\text { of farms }\end{array}$ & $\begin{array}{r}\text { (thousand } \\
\text { EUR) }\end{array}$ & 175.0 & 138.4 & 316.9 & 29.3 & 269.4 & 138.9 \\
\hline $\begin{array}{l}\text { Utilised agricultural } \\
\text { area (UAA) }\end{array}$ & (ha) & 69.74 & 86.89 & 105.91 & 20.95 & 49.85 & 28.24 \\
\hline Share of rented UAA & $(\%)$ & 64.7 & 90.0 & 40.5 & 25.9 & 38.5 & 63.1 \\
\hline $\begin{array}{l}\text { The number } \\
\text { of full-time employees }\end{array}$ & (AWU) & 1.96 & 1.82 & 2.61 & 1.81 & 1.73 & 2.00 \\
\hline including: $\begin{array}{l}\text { unpaid total } \\
\text { input (FWU) }\end{array}$ & $(\%)$ & 72.7 & 90.9 & 61.9 & 97.0 & 89.0 & 78.3 \\
\hline $\begin{array}{l}\text { Number } \\
\text { of full-time employees } \\
\text { per } 100 \text { ha of UAA }\end{array}$ & (AWU) & 2.81 & 2.09 & 2.46 & 8.65 & 3.46 & 7.08 \\
\hline Total assets & (EUR/farm) & 802,744 & 416,556 & $1,600,521$ & 197,907 & $2,758,085$ & 948,971 \\
\hline Fixed assets & (EUR/farm) & 701,960 & 295,202 & $1,451,609$ & 177,451 & $2,510,099$ & 635,937 \\
\hline $\begin{array}{l}\text { Share of land }(Z) \\
\text { in fixed assets }\end{array}$ & $(\%)$ & 60.9 & 11.7 & 72.6 & 50.7 & 79.1 & 65.7 \\
\hline \multirow{3}{*}{$\begin{array}{l}\text { Fixed assets } \\
\text { without land (Z) }\end{array}$} & (EUR/farm) & 274,223 & 260,590 & 398,262 & 87,443 & 524,211 & 218,278 \\
\hline & (EUR/ha) & 3,932 & 2,999 & 3,760 & 4,174 & 10,516 & 7,730 \\
\hline & (EUR/AWU) & 139,731 & 143,181 & 152,883 & 48,244 & 303,890 & 109,139 \\
\hline $\begin{array}{l}\text { Structure of fixed assets } \\
\text { without land (Z) }\end{array}$ & $(\%)$ & 100.0 & 100.0 & 100.0 & 100.0 & 100.0 & 100.0 \\
\hline \multirow{2}{*}{$\begin{aligned} \text { of which: buildings (B) } \\
\text { machinery (M) }\end{aligned}$} & & 39.3 & 42.2 & 25.8 & 46.0 & 55.7 & 44.0 \\
\hline & & 39.4 & 31.5 & 31.2 & 39.5 & 25.5 & 29.7 \\
\hline breeding herd (S) & & 21.3 & 26.3 & 43.0 & 14.5 & 18.8 & 26.3 \\
\hline Current assets & (EUR/farm) & 100,784 & 121.354 & 148,912 & 20,455 & 247,986 & 313,035 \\
\hline
\end{tabular}

Explanations: (Z) - land, permanent crops and production quotas; (B) - buildings and their permanent equipment, (M) - machinery, equipment and means of transport; $(\mathrm{S})$ - female animals from the breeding herd.

Source: own study based on the EU FADN (Farm Accountancy..., 2017). 
From the data presented in Table 1 it results that the economic size of the farms (calculated based on the standard output coefficients ${ }^{11}$ ), focused on the milk production in the countries included in the analysis was very diverse. On average, in 2010-2013 the greatest economic power was characteristic of the farms from Great Britain (EUR 316.9 thousand) and the smallest - of the Polish farms (EUR 29.3 thousand). By comparing these extreme values, the diversity was 10.8 -fold.

The level of equipping farms with production factors also was different. Labour resources expressed by the number of full-time employees (AWU) showed the difference of 1.5 times; the biggest differences were characteristic of the farms from Great Britain (2.61 AWU), and the smallest - of those from the Netherlands (1.73 AWU). In terms of labour intensity, the differences were larger, per 100 ha of UAA this production factor was the most abundant in Poland - 8.65 AWU, and the least in France - 2.09 AWU. This means that in Poland labour intensity of production was 4.1 times higher. The farms to a various extent supported their activity by means of paid labour. The share of unpaid labour input expressed in full-time employees (FWU) in total labour input (AWU) was the highest in Poland (97.0\%), and lowest in Great Britain (61.9\%).

The results show that land resources of the Polish farms were the smallest, the average utilised agricultural land was 20.95 ha and was 5.1 times smaller when compared to the farms from Great Britain (105.91 ha), which were largest in terms of their area. The utilised agricultural area of the Polish farms was, however, to the greatest extent $(74.1 \%)$ own resource of farm families (share of rented UAA was $25.9 \%$ ). The smallest share of own land was recorded for the French farms $(10.0 \%)$.

Another element of the assessment of the farms' production potential are assets (total assets). The results of the studies show that total assets were dominated by fixed assets, their share ranged from $67.0 \%$ on the Italian farms to 91.0\% on the Dutch farms. According to the literature, if farms' assets are dominated by fixed assets, the possibilities of adapting the size and structure of these assets to market changes are lower (Ćwiąkała-Małys and Nowak, 2001). The consequence is low flexibility of the farms, as fixed assets are definitely less liquid than current assets. Fixed assets are involved for longer periods, and the process of their conversion into cash is usually long-term. This is characteristic of the farms, due to some specific features of agriculture, for example, long production cycle.

On average, in 2010-2013 the value of fixed assets was strongly differentiated when comparing the extreme values up to 14.1 times. The main reason was more than 57-fold differentiation of the value of land (on the French farms,

\footnotetext{
${ }^{11}$ Standard output is the average (from 5 years) output value of specific crop or animal production activity derived from 1 ha or 1 animal within 1 year, in the conditions average for the given region (Bocian, Cholewa and Tarasiuk, 2015).
} 
the value of land was EUR 34.6 thousand, while on the Dutch farms - EUR 1,985.9 thousand). In almost all countries, in the value of assets there was the high share of land, from $50.7 \%$ on the Polish farms to $79.1 \%$ on the Dutch farms. The only exception were the French farms, where the share of land was $11.7 \%$. This results mostly from the land ownership structure, on the French farms only $10.0 \%$ of used land belonged to the farmer (another question is the land valuation rules, which could also be revised over the years). The differentiation of value of fixed assets without the land value was 6-fold. In their structure, the largest share was that of buildings and machinery, only in Great Britain the largest was the share of the value of the breeding herd (43.0\%), and the lowest - of the value of buildings $(25.8 \%)$.

The specificity of the agricultural production on the farms of each country also influences the diversification of current assets. The greater number of directions of production usually involves a need to have, e.g. larger stocks, while the farm specialisation allows to optimise their size. On the analysed farms, the share of current assets 0n total assets ranged from $9.0 \%$ in the Netherlands to $33.0 \%$ in Italy.

Production organisation on the farms. The standard FADN results do not allow for a complete analysis of production organisation (they do not contain data on the structure of utilised agricultural area (UAA), making it difficult to analyse the structure of sowings), therefore, only selected issues were analysed. A determinant of crop production organisation was the share of crop groups in UAA. From the data contained in Table 2, it results that on the analysed farms specialised in milk production, the crop production was dependent on livestock production. This is evidenced by the share of the area taken for fodder crops ${ }^{12}$ (i.e. forage area) in the utilised agricultural area, which ranged from $60.6 \%$ in Poland to $97.7 \%$ in the Netherlands. Taking into account the share of cereals in the utilised agricultural area, it should be noted that in this respect, Poland differs greatly from other countries. The share of cereals in Poland was the largest and amounted to $35.8 \%$, while it was the lowest in Great Britain and in the Netherlands - respectively, 7.6 and $1.0 \%$. The larger share of cereals in the UAA structure points to the larger opportunities of providing, for dairy cows, concentrate feed from own production, which results in reducing costs and increasing the milk production profitability. However, due to relatively large share of cereals in the utilised agricultural area in Poland the share of fodder crops was lower than in other countries.

\footnotetext{
${ }^{12}$ According to the FADN, fodder crops include: fodder root and brassica vegetables, other fodder crops, grass grown in the open, meadows and permanent pastures and rough grazing (Floriańczyk, Mańko, Osuch and Płonka, 2014).
} 
Table 2

Production organisation on the farms focused on milk production in the selected EU countries, on average, in 2010-2013

\begin{tabular}{|c|c|c|c|c|c|c|c|}
\hline Specification & & Germany & France & $\begin{array}{c}\text { Great } \\
\text { Britain }\end{array}$ & Poland & Netherlands & Italy \\
\hline $\begin{array}{l}\text { Share of the area of cereals in } \\
\text { utilised agricultural area (UAA) }\end{array}$ & $(\%)$ & 22.4 & 20.2 & 7.6 & 35.8 & 1.0 & 15.5 \\
\hline Share of fodder crops in UAA & $(\%)$ & 72.1 & 77.5 & 90.8 & 60.6 & 97.7 & 81.9 \\
\hline Total livestock & (LU/farm) & 93.8 & 94.4 & 197.1 & 22.7 & 120.6 & 74.7 \\
\hline including: dairy cows & & 54.0 & 52.6 & 122.0 & 14.7 & 83.0 & 47.4 \\
\hline other cattle & & 38.4 & 40.6 & 67.9 & 7.5 & 34.9 & 27.0 \\
\hline Dairy cows per 100 ha of UAA & (LU) & 77.4 & 60.6 & 115.2 & 70.3 & 166.5 & 167.8 \\
\hline Milk yield of cows & $(\mathrm{kg} / \mathrm{cow})$ & 7,535 & 6,789 & 7,347 & 5,178 & 7,943 & 6,133 \\
\hline Milk price & $(\mathrm{EUR} / 100 \mathrm{~kg})$ & 33.81 & 33.34 & 32.12 & 29.33 & 35.40 & 37.02 \\
\hline $\begin{array}{l}\text { Share of livestock production } \\
\text { in a total production valuein } \\
\text { a farm }\end{array}$ & $(\%)$ & 80.7 & 84.3 & 87.5 & 80.4 & 91.3 & 80.7 \\
\hline $\begin{array}{l}\text { Share of the milk and dairy } \\
\text { products production in total } \\
\text { production value on a farm }\end{array}$ & $(\%)$ & 67.5 & 69.3 & 75.3 & 65.3 & 83.0 & 71.3 \\
\hline
\end{tabular}

Source: own study based on the EU FADN (Farm Accountancy..., 2017; European Commission, 2017).

Due to the manner of selection of the sample of farms, the livestock kept in the farms (expressed in livestock units - $\mathrm{LU}^{13}$ ) was dominated by dairy cows, their share ranged from 55.8 to $68.8 \%$ (respectively, in France and the Netherlands), but the share of other cattle was also high, ranging from 29.0 to $43.0 \%$ (respectively, in the Netherlands and France). These may prove a simultaneous rearing of born calves and at least to some extent the focus on milk production with own herd reproduction. In a synthetic way, the density of dairy cows kept on the farms is determined by their number per 100 ha of utilised agricultural area (which indicates the intensity of organisation). The calculations show that in three countries, i.e. France, Poland and Germany, the density of cows on the farms was similar and fell within the lower quantitative range among six countries covered by the study, ranging from 60.6 to 77.4 LU. In the Netherlands and in Italy, it was higher more than twice, amounting to, respectively, 166.5 and 167.8 LU, while in Great Britain it was 115.2 LU.

Bearing in mind the discussed issues, of great importance is milk production from $1 \mathrm{cow}$, which is one of the indicators evidencing the results of the livestock production. Important is also the selling price of milk. The results of the studies

\footnotetext{
${ }^{13}$ Livestock unit, e.g. dairy cows $=1 \mathrm{LU}$, cattle aged 1-2 years $=0.7$ LU (Floriańczyk, Mańko, Osuch and Płonka, 2014).
} 
indicate that the milk yield of cows was diversified from country to country. On average, in the years covered by the studies (2010-2013) it was from $5,178 \mathrm{~kg} /$ cow on the Polish farms to $7,943 \mathrm{~kg} / \mathrm{cow}$ on the Dutch farms. This means that in Poland, the milk yield of cows was lower by $34.8 \%$. The average milk price over the years was the lowest in Poland (EUR 29.33/100 kg), while the highest price of milk (EUR $37.02 / 100 \mathrm{~kg}$ ) was obtained by Italian farmers. In the value structure of the value of farms' production, all analysed countries were dominated by the livestock production, its share ranged from $80.4 \%$ in Poland to $91.3 \%$ in the Netherlands. On the other hand, the share of milk and dairy products production in the total production of a farm amounted to $65.3-83.0 \%$, respectively in the same countries (Table 2).

Economic results of the farms net value added reflects payment for all production factors, i.e. labour, land and capital, no matter by whom they are owned. This income category is appropriate for analysing the economic results of the farms regardless of the situation in the field of ownership of production factors. At this level of analysis, the effect of external factors, namely paid labour, rent and interest on credit on the cost results is eliminated (Goraj and Mańko, 2004).

The studies show that the ownership structure of production factors on the farms from the study sample was strongly differentiated. This is evidenced by, e.g., the share of the cost of external factors in total costs of the farms, which was contained within the limits of 4.2-19.0\%. The farms the least burdened with the cost of using external production factors, taking into account its share in total costs and in value terms, were the Polish farms, while the highest burden was noted for the Dutch farms - Table 3.

Table 3

Net value added and economic performance of land and labour on the farms focused on milk production in the selected EU countries, on average, in 2010-2013

\begin{tabular}{lrcccccc}
\hline \multicolumn{1}{c}{ Specification } & & Germany & France & $\begin{array}{c}\text { Great } \\
\text { Britain }\end{array}$ & Poland & Netherlands & Italy \\
\hline $\begin{array}{l}\text { Net value added less } \\
\text { subsidies to the operating }\end{array}$ & $\begin{array}{r}\text { (EUR/farm) } \\
\text { activity of the farm }\end{array}$ & 41,923 & 23,544 & 80,727 & 9,281 & 88,586 & 74,627 \\
$\begin{array}{l}\text { (EUR/ha) } \\
\text { of UAA) }\end{array}$ & 601 & 271 & 762 & 443 & 1,777 & 2,643 \\
$\begin{array}{l}\text { Cost of external factors } \\
\begin{array}{l}\text { Share of the cost of external } \\
\text { factors in total }\end{array}\end{array}$ & $\begin{array}{l}\text { (EUR/farm) } \\
\text { costs of the farm }\end{array}$ & 21,362 & 12,936 & 30,989 & 5,120 & 51,354 & 37,313 \\
& $(\%)$ & 13.8 & 11.3 & 11.8 & 4.2 & 19.0 & 10.0
\end{tabular}

Source: own study based on the EU FADN (Farm Accountancy..., 2017).

Maximising the economic effects is the objective of all economic entities, but their size depends on many factors, both endo- and exogenous. The first group includes mainly the production volume and its technical efficiency, and the other 
- institutional and price mechanisms (Czyżewski and Kryszak, 2015). For this reason, the highest net value added has been achieved by the Dutch farms (EUR 88,586 per farm), and the lowest - by the Polish farms (EUR 9,281 per farm). At the same time, the Dutch farms were characterised by the highest economic labour productivity (measured by net value added per 1 AWU) and the relatively high economic land productivity (measured by net value added per ha of UAA). Net value added on the Polish farms significantly deviates from the level achieved in other countries. The same applies to economic labour productivity (EUR 5,120 per AWU), this is alarming as it indicates the much lower standard of living. In terms of the economic labour productivity, the worst situation was that of the French farms (EUR 271 per ha), the situation of the Polish farms was slightly better (EUR 443 per ha). The highest land productivity was that of the Italian farms (EUR 2,643 per ha) (Table 3).

Table 4

Economic and production results of farms focused on milk production in the selected EU countries, on average, in 2010-2013

\begin{tabular}{|c|c|c|c|c|c|c|c|}
\hline Specification & & Germany & France & $\begin{array}{l}\text { Great } \\
\text { Britain }\end{array}$ & Poland & Netherlands & Italy \\
\hline Total production value & (EUR/farm) & 214,441 & 178,859 & 391,125 & 32,931 & 308,656 & 191,197 \\
\hline Total costs & (EUR/farm) & 202,059 & 173,268 & 351,254 & 24,546 & 266,960 & 128,136 \\
\hline \multirow{2}{*}{$\begin{array}{l}\text { Farm income } \\
\text { without subsidies }\end{array}$} & (EUR/farm) & 11,762 & 5,479 & 41,432 & 8,422 & 37,074 & 62,339 \\
\hline & (EUR/FWU) & 8,240 & 3,310 & 25,694 & 4,792 & 24,153 & 39,833 \\
\hline $\begin{array}{l}\text { Subsidies to the operating } \\
\text { activity of the farm }\end{array}$ & (EUR/farm) & 32,614 & 32,216 & 33,339 & 6,305 & 27,840 & 14,912 \\
\hline \multirow{2}{*}{$\begin{array}{l}\text { Farm income } \\
\text { with subsidies }\end{array}$} & (EUR/farm) & 44,376 & 37,695 & 74,771 & 14,728 & 64,914 & 77,252 \\
\hline & (EUR/FWU) & 31,087 & 22,776 & 46,370 & 8,380 & 42,289 & 49,362 \\
\hline $\begin{array}{l}\text { Share of subsidies to the } \\
\text { operating activity in farm } \\
\text { income with subsidies }\end{array}$ & $(\%)$ & 73.5 & 85.5 & 44.6 & 42.8 & 42.9 & 19.3 \\
\hline $\begin{array}{l}\text { Subsidies to the operating } \\
\text { activity per EUR } 1 \\
\text { of income without subsidies }\end{array}$ & (EUR) & 2.77 & 5.88 & 0.80 & 0.75 & 0.75 & 0.24 \\
\hline $\begin{array}{l}\text { Ratio of farm income } \\
\text { without subsidies } \\
\text { to the production value }\end{array}$ & $(\%)$ & 5.5 & 3.1 & 10.6 & 25.6 & 12.0 & 32.6 \\
\hline $\begin{array}{l}\text { Total costs of manufacturing } \\
\text { EUR } 100 \text { of production }\end{array}$ & (EUR) & 94 & 97 & 90 & 75 & 86 & 67 \\
\hline $\begin{array}{l}\text { Total costs of achieving } \\
\text { EUR } 100 \text { of farm income } \\
\text { without subsidies }\end{array}$ & (EUR) & 1,718 & 3,163 & 848 & 291 & 720 & 206 \\
\hline
\end{tabular}

Source: own study based on the EU FADN (Farm Accountancy..., 2017). 
Farm income is the economic result of the economic activity, its amount determines the level of meeting consumer needs of the farmer's family and the development opportunities of the farm. The objective of agricultural producers is to strive for increasing income, as its level determines payment for unpaid labour of the farmer and his family members, and payment for other involved production factors owned by the farm family, i.e. land and capital.

Income of farms specialised in the milk production in the countries with the largest milk production in the EU were very diverse. The highest income without subsidies was achieved in the Italian farms - EUR 62.3 thousand. The lower and similar to each other level was that of income without subsidies, achieved by milk producers in Great Britain and the Netherlands, where it was, respectively, EUR 41.4 thousand and EUR 37.1 thousand per farm. Further positions were occupied by the farms in Germany and Poland, where income without subsidies was, respectively, EUR 11.8 thousand and EUR 8.4 thousand. The income situation of the French farms was least favourable, income without subsidies amounted only to EUR 5.5 thousand (Table 4).

Subsidies recorded at the farm level directly affect the income level of farms. However, the strength of their impact is determined by the value of economic surpluses obtained from the production and amounts of subsidies received. The results indicate that per EUR 1 of income without subsidies, the highest level subsidies (EUR 5.88) was noted on the French farms, and their share in farm income with subsidies was very high $-85.5 \%$. The lowest impact on the results was that of subsidies on the Italian farms, per EUR 1 of income without subsidies there was only EUR 0.24 of subsidies, and their share in income with subsidies was $19.3 \%$. Thanks to subsidies, the income situation of the farms has greatly improved, especially the French farms. Among the analysed countries, farm income without subsidies placed those entities in the last position, while thanks to subsidies they moved to the penultimate position.

The agricultural production is a complex process and the development of the farms is affected also by external factors resulting from the external impact on agriculture, regardless of internal factors arising from the quality and method of using the production potential i.e. land, labour and capital resources. The studies by Poczta et al. (2009) show that the income situation of the farms is determined by the size of the production potential, intensity of production and agricultural policy. Zegar (2001) is of similar opinion, according to this author, farm income depends on the individual productivity and on the conditions created by institutions. In agriculture, income is generally lower than in other sections of the economy, therefore, it is supported by direct payments. Their objective is to compensate farmers for income which is lower when compared to other sections of the economy. Subsidies contribute to the increase in farm income, however, this increase does not result from the improved efficiency of the agricultural production (Babuchowska and Marks-Bielska, 2011). 
The studies show that the highest profitability was characteristic of the farms focused on the milk production in Italy, measured by the ratio of farm income without subsidies to the production value, which amounted to $32.6 \%$. The second place was occupied by the Polish farms - the share of income without subsidies in the production value was $25.6 \%$. Italy and Poland are the countries which, against a background of other countries, stand out positively in terms of the production profitability. In the Dutch and British farms, this ratio was not so beneficial and amounted, respectively, to 12.0 and $10.6 \%$. Even weaker results were achieved by the German and French farms - the share of income without subsidies in the farm production value was, respectively, 5.5 and $3.1 \%$. This means that the production profitability in the study sample of the farms in these countries - against a background of other countries - was the lowest.

In assessing the economic efficiency of management, the ratio of costs to the production value and to farm income without subsidies was also used. The results of the calculations indicate the important role of costs in the production process. Total costs of manufacturing EUR 100 of production were quite strongly diversified. The highest costs (EUR 97) were recorded on the farms focused on milk production in France, and the lowest (EUR 67) in Italy, the difference in favour of the Italian farms was $30.9 \%$. The results of the Polish farms were also quite favourable, manufacturing EUR 100 of production cost EUR 75, or the advantage in relation to the weakest in this respect French entities was $22.7 \%$. It can, therefore, be concluded that the farms focused on milk production in Italy and Poland, when compared to other countries, are characterised by high competitiveness in terms of costs they incur.

The greater diversification of farms from the study sample is indicated by the cost of obtaining income unit without subsidies. By comparing the extreme values, the diversity was 15.4-fold. On the Italian farms, the cost of obtaining EUR 100 of income without subsidies was lowest, it amounted to EUR 206. The second position was occupued by the Polish farms - EUR 291. On the other hand, the French and German farms, costs of obtaining EUR 100 income without the payments were in highest, amounting, respectively, to EUR 3,163 and EUR 1,718. The level of costs had a strong impact on the efficiency of the analysed farms (Table 4).

When analysing the efficiency of production on the farms from the study sample, the productivity of inputs was also assessed. In market economy, the increase in the productivity is considered to be the primary factor of economic growth and improvement in the living conditions of the population. Analysis of productivity of current inputs measured by intermediate consumption value (intermediate consumption is expressed by total direct costs and overheads related to the functioning of the farm) allows us to learn how their management translates into products manufactured. 
Table 5

Selected indicators describing the production and economic situation of farms focused on milk production in the selected EU countries, on average, in 2010-2013

\begin{tabular}{lccccccc}
\hline \multicolumn{1}{c}{ Specification } & & Germany & France & $\begin{array}{c}\text { Great } \\
\text { Britain }\end{array}$ & Poland & Netherlands & Italy \\
\hline $\begin{array}{l}\text { Productivity of current } \\
\text { inputs }\end{array}$ & $(\%)$ & 150.2 & 150.7 & 143.5 & 179.2 & 177.6 & 191.3 \\
$\begin{array}{l}\text { Productivity of fixed } \\
\text { capital inputs }\end{array}$ & (times) & 6.8 & 5.1 & 10.5 & 6.4 & 7.3 & 12.5 \\
$\begin{array}{l}\text { Share of the cost } \\
\text { of depreciation }\end{array}$ & $(\%)$ & 15.6 & 20.2 & 10.6 & 20.9 & 15.9 & 12.0 \\
in total costs & & & & & & & \\
\end{tabular}

Source: own study based on the EU FADN (Farm Accountancy..., 2017).

The results contained in Table 5 indicate a clear advantage of the Italian farms, the productivity of current inputs was $191.3 \%$ (which means that the obtained production value exceeded the value of inputs by $91.3 \%$ ). The higher is the value of this index, the better, this points to, e.g., better management of the production process ${ }^{14}$. The second position was occupied by the Polish farms, the productivity of current inputs was $179.2 \%$. A similar productivity level was also achieved by the Dutch farms $-177.6 \%$. In the sample of the German, French and British farms, the productivity of financial inputs was much lower, within the range of $143.5-150.7 \%$.

The productivity of fixed capital is expressed by the production value per PLN 1 of depreciation of fixed assets on the farm. This kind of productivity reflects the degree of intensity of using fixed assets in the production process, therefore, it describes its activity. The results obtained show a clear advantage of the analysed farms from Italy and Great Britain, while the relatively low productivity of fixed capital was characteristic of the French and Polish farms. It should be added that the productivity of fixed capital shows a relationship involving the cost of depreciation of fixed assets in total costs of the farm. On the farms specialised in milk production in Poland and France, this share was the highest (respectively, 20.9 and 20.2\%), while the productivity of fixed capital was the lowest (Table 5).

Use of assets of farms. Based on the criterion of the investor's legal status, we may identify own capital and foreign capital. Own capital is capital left at the disposal of the enterprise by its owners. In return, owners may have income or profit at their disposal. Foreign capital is capital left at the disposal of the

\footnotetext{
${ }^{14}$ In the traditional and most common aspect, the productivity level is determined as a function of owned resources (employment, capital, labour resources), their use and market conditions (sales volume and income). Each factor influences the achieved productivity level. The improvement in productivity indicates the efficiency of the management team's activities, it is identified with good governance, but on the other hand, and is associated with the process of change (Lis (ed.), 1999).
} 
enterprise for a specified period and must be returned to its owner. Reducing the ratio of liabilities to capital turnover, we can conclude that the debtor undertakes to repay the obtained capital received together with a remuneration to the capital lender (Kulawik, 1995). Foreign capital in a form of credit for a single farm is a complement to its own resources at times of the greatest demand for financial resources and allows the form to extend the capital base to longer periods, resulting in greater engagement of capital in fixed assets, i.e. implementing investments on the farm (Czerwińska-Kayzer, 2002, as in: Giselbrecht, 1991).

Table 6

Characteristics of the financial situation of farms focused on milk production in the selected EU countries, on average, in 2010-2013

\begin{tabular}{lccccccc}
\hline \multicolumn{1}{c}{ Specification } & & Germany & France & $\begin{array}{c}\text { Great } \\
\text { Britain }\end{array}$ & Poland & Netherlands & Italy \\
\hline Own capital & (EUR/farm) & 653,323 & 238,595 & $1,371,006$ & 186,668 & $1,912,537$ & 938,530 \\
Total liabilities & (EUR/farm) & 149,422 & 177,961 & 229,516 & 11,239 & 845,547 & 10,441 \\
of which: short-term & & 37,556 & 47,031 & 87,346 & 2,717 & 48,021 & 256 \\
\multicolumn{1}{c}{ long-term } & & 111,866 & 130,930 & 142,170 & 8,521 & 797,526 & 10,185 \\
Gross investments & (EUR/farm) & 43,205 & 32,754 & 65,730 & 6,501 & 85,350 & 17,278 \\
Depreciation & (EUR/farm) & 31,481 & 34,951 & 37,253 & 5,130 & 42,536 & 15,332 \\
Net investments & (EUR/farm) & 11,724 & $-2,197$ & 28,476 & 1,371 & 42,814 & 1,946
\end{tabular}

Source: own study based on the EU FADN (Farm Accountancy..., 2017).

When assessing the share of own capital in financing the value of assets, we can specify the risk of pursuing the activity incurred by the farm. Generally, it is believed that the higher is this share, the lower is the rsik, and the economic situation of the farms - better. The studies show that, on average, on 2010-2013 in those farms own capital financed $57-99 \%$ of the value of total assets (on the French farms $-57.3 \%$, Dutch $-69.3 \%$, German $-81.4 \%$, British $-85.7 \%$, Polish $-94.3 \%$, Italian $-98.9 \%$ ). Therefore, liabilities financed only a few per cent of the value of assets on the Italian farms (1.1\%) and Polish farms (5.7\%), while as much as $42.7 \%$ on the French farms (Table 1 and 6).

Investments made by the farms determine their development, particularly net investments, whose value exceeds the value of fixed assets consumed in the production process (consumption of fixed capital is expressed by depreciation). Taking into account net investments, the situation of dairy farms in five countries was favourable, i.e. in Germany, Great Britain, Poland, the Netherlands and Italy. Net investments were positive, which means that the value of investments made exceeded depreciation. These were development investments, i.e. 
the process of reproduction of fixed assets was faster than the process of their aging. The exception were only the French farms, in which net investments were negative (EUR -2,197). This shows that the process of reproduction of fixed assets was slower than the process of their aging. This may suggest that farmers lacked the funds or overinvested on their farms in the previous years.

The data contained in Table 7 more precisely describes this issue. It indicates that the farms focused on milk production in Germany, Great Britain and the Netherlands were characterised by extended reproduction of fixed assets, the reproduction rate was within the range of 1.7-2.0\%. On the Polish and Italian farms, there was simple reproduction, the index was, respectively, 0.8 and $0.3 \%$. The reproduction rate of fixed assets on the French farms $(-0.7 \%)$ also points to simple reproduction, but the level of their reproduction was lower than on the Polish and Italian farms. This means that French farmers modernised their assets much slower.

Table 7

Selected indicators describing the financial risk and predisposition to the restructuring of farms focused on the milk production in the selected EU countries, on average, in 2010-2013

\begin{tabular}{|c|c|c|c|c|c|c|c|}
\hline Specification & & Germany & France & $\begin{array}{c}\text { Great } \\
\text { Britain }\end{array}$ & Poland & Netherlands & Italy \\
\hline $\begin{array}{l}\text { Reproduction rate } \\
\text { of fixed assets }\end{array}$ & $(\%)$ & 1.7 & -0.7 & 2.0 & 0.8 & 1.7 & 0.3 \\
\hline Farm debt level & $(\%)$ & 18.6 & 42.7 & 14.3 & 5.7 & 30.7 & 1.1 \\
\hline Debt structure index & $(\%)$ & 74.9 & 73.6 & 61.9 & 75.8 & 94.3 & 97.6 \\
\hline $\begin{array}{l}\text { Asset immobilisation } \\
\text { ratio }\end{array}$ & (times) & 2.7 & 2.1 & 2.7 & 4.3 & 2.1 & 0.7 \\
\hline
\end{tabular}

Source: own study based on the EU FADN (Farm Accountancy..., 2017).

To assess the farm debt level, the index calculated as a ratio of liabilities to the value of total assets was used. The value of this index was diversified on the farms from the individual countries, however, it did not exceed $50 \%$ in any of them. This is important, as it is assumed that the value of the index exceeding $50 \%$ involves a significant increase in risk in financing the enterprise (Ziętara, 1998). The results show that most indebted were the French farms, the index defining the debt level was $42.7 \%$. Lower, but also rather large debt was characteristic of the Dutch farms $-30.7 \%$. This means that farmers in those countries were quite willing to use credits. Debt of the German and British farms was smaller and was at the similar level, the debt level index was, respectively, 18.6 and $14.3 \%$. Least indebted were the Polish and Italian farms, the index specifying the share of liabilities in financing property assets was, respectively, 5.7 and 1.1\%. 
In considering the structure of liabilities, it should be noted that in the Dutch and Italian farms almost all were long-term credits, their share in total liabilities was, respectively, 94.3 and $97.6 \%$. On the farms of other countries, the structure of liabilities was similar, the share of long-term credits was within the range of $61,9-75,8 \%$. Long-term credits are usually allocated for investments, so it may mean the further development of the farms.

The ratio of the value of fixed assets (excluding the value of land ${ }^{15}$ ) to current assets was adopted as the indicator of the flexibility of the farms in adapting to market changes. From the calculations contained in Table 7, it results that the Italian farms have the greatest opportunities in terms of the efficient use of resources they own. The asset immobilisation ratio reflecting the above relationship, was lower than 1.0 (amounting 0.7 ), which means that the value of current assets exceeded the value of fixed assets (43.4\%). On the farms specialised in milk production in other countries, the asset immobilisation ratio ranged from 2.1 (in the Netherlands and France) to 4.3 (in Poland). The value of the ratio higher than 1.0 indicates large share of fixed assets in farm assets which generate high fixed costs and limit the ability to achieve income. This means that the potential capacity to transform the farms focused on milk production in Poland was lower than in other countries. According to literature, the asset structure dominated by current assets is more favourable for farms, as these assets create opportunities for adaptation to market needs (competitiveness), improve financial liquidity, and consequently contribute to the growth of income (Bieniasz and Gołaś, 2008).

\section{Economic results of dairy farms in Poland in 2014-2015 based on the Polish FADN data}

The results included in Table 8 indicate a significant deterioration in 2015, when compared to 2014, of the income situation of the dairy farms in Poland (type - dairy cows). Revenues (production value) in this group of farms decreased by $13.5 \%$, and farm income without subsidies by $50.7 \%$ (the same decrease related to income per 1 full-time employee - FWU). In 2015, due to changes in the system of direct payments, subsidies to the operating activity of the farm increased by $33.2 \%$ (i.e. by PLN 8,437 per farm). As a result, to PLN 1 of income without subsidies farmers received support for payments amounting to PLN 1.96 (in 2014 - PLN 0.72), and their share in income with subsidies amounted to $66.2 \%$ (2014-42.0\%). However, despite this fact farm income with subsidies did not reach the level from 2014, it was by $15.4 \%$ lower (PLN 51,118, while in 2014 - PLN 60,434). In 2015, due to lower revenues the economic efficiency of production deteriorated. Total costs of manufacture of

\footnotetext{
${ }^{15}$ In calculating the ratio of fixed assets to current assets, the value of land was ignored (e.g., due to the large differences among the countries in terms of the share of own land in utilised agricultural area in total).
} 
PLN 100 of production increased by $12.6 \%$ (although their level on the farm decreased by $2.6 \%$ ). In addition, the profitability of production decreased by $43.0 \%$, and costs of obtaining PLN 100 of farm income without subsidies increased by $97.5 \%$.

Farm income determines the achievement of competitive advantage of farms, but also its amount per 1 family member employed full-time (FWU) shows the potential amount of payment for labour of the farmer and his family members. Farm income with subsidies in 2014 was PLN 34,338 per FWU and in 2015 - PLN 29,044 per FWU. By comparing this income with parity income, we can specify whether the farmer reaches payment of unpaid labour at the level reached by those employed in the national economy. The studies showed that in 2014 income per 1 family member employed full-time was by $13.3 \%$ higher than the average salary in the national economy, while in 2015 it was only $93.0 \%$ of its level (parity income per 1 full-time employee in 2014 was PLN 30,302 , and in 2015 - PLN $31,233^{16}$ ). Therefore, it can be considered that in 2014 the farms keeping 16 cows with the milk yield of about $5,300 \mathrm{~kg}$ and supported by subsidies, met the requirements of the parity farm. Unfortunately, in 2015 the economic results of the farms worsened and it was not fully possible. However, it must be added that without support of payment, the situation would be much worse. In 2014, farm income without subsidies per 1 family member employed full-time (FWU) accounted for $65.7 \%$ of the average salary in the national economy, and in 2015 - only $31.5 \%$.

The deterioration in 2015, when compared to 2014, in the results of the dairy farms was highly determined by the fall in milk price. On average, in the study sample of the farms, milk price fell by $16.5 \%$ (in 2014, it was PLN 1.39 per litre, and in 2015 - PLN 1.16 per litre), while according to the GUS data (GUS, 2016) in 2015 , on average in the country the milk price was lower by $17.5 \%$ (in 2014 , it was PLN 1.37 per litre, and in 2015 - PLN 1.13 per litre).

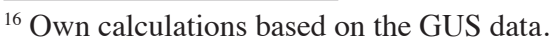


Table 8

Economic and production results of farms focused on milk production in Poland in 2014-2015

\begin{tabular}{|c|c|c|c|c|}
\hline \multirow{2}{*}{ Specification } & & \multicolumn{2}{|c|}{ Years of studies } & \multirow{2}{*}{$\begin{array}{c}\text { Index of } \\
\text { change } \\
2014=100\end{array}$} \\
\hline & & 2014 & 2015 & \\
\hline Total production value & (PLN/farm) & 148,616 & 128,600 & 86.5 \\
\hline Total costs & (PLN/farm) & 113,898 & 110,983 & 97.4 \\
\hline \multirow{2}{*}{ Farm income without subsidies } & (PLN/farm) & 35,042 & 17,289 & 49.3 \\
\hline & PLN/FWU) & 19,910 & 9,823 & 49.3 \\
\hline $\begin{array}{l}\text { Subsidies to the operating activity } \\
\text { of the farm }\end{array}$ & $(\mathrm{PLN} / \mathrm{farm})$ & 25,392 & 33,829 & 133.2 \\
\hline \multirow{2}{*}{ Farm income with subsidies } & (PLN/farm) & 60,434 & 51,118 & 84.6 \\
\hline & (PLN/FWU) & 34,338 & 29,044 & 84.6 \\
\hline $\begin{array}{l}\text { Ratio of income with subsidies per } 1 \mathrm{FWU} \\
\text { to the net salary in the national economy }\end{array}$ & $(\%)$ & 113.3 & 93.0 & 82.1 \\
\hline $\begin{array}{l}\text { Share of subsidies to the operating activity } \\
\text { in farm income with subsidies }\end{array}$ & $(\%)$ & 42.0 & 66.2 & 157.5 \\
\hline $\begin{array}{l}\text { Subsidies to the operating activity } \\
\text { per PLN } 1 \text { of income without subsidies }\end{array}$ & $(\mathrm{PLN})$ & 0.72 & 1.96 & 270.0 \\
\hline $\begin{array}{l}\text { Ratio of farm income without subsidies } \\
\text { to the production value }\end{array}$ & $(\%)$ & 23.6 & 13.4 & 57.0 \\
\hline $\begin{array}{l}\text { Total costs of manufacture of PLN } 100 \\
\text { of the production }\end{array}$ & $(\mathrm{PLN})$ & 77 & 86 & 112.6 \\
\hline $\begin{array}{l}\text { Total costs of obtaining PLN } 100 \text { of farm } \\
\text { income without subsidies }\end{array}$ & $(\mathrm{PLN})$ & 325 & 642 & 197.5 \\
\hline
\end{tabular}

Source: own study based on the EU FADN Polish data (Floriańczyk, Osuch and Płonka, 2015; Floriańczyk, Osuch and Płonka, 2016).

The functioning of the milk market until 30 March 2015 was based on milk quotas, thus it was governed by the instruments of the EU agricultural policy. The abolition of milk production quotas and, therefore, the increase in its supply, contributed to the fall in the milk prices. In addition, the situation on milk market in Poland and the adverse impact on the level of prices, in addition to the increased supply, was also determined by the Russian embargo on import of food from the EU and other countries as well as fall in the prices of milk and dairy products in the global market (Rynek mleka ..., 2015).

\section{Summary and conclusions}

On average, in 2010-2013 Poland ranked fourth among the largest producers of cow's milk in the EU-28 (after Germany, France and Great Britain, and before the Netherlands and Italy), with the share of $8.1 \%$ (while it was ranked first among the EU-N13 countries with the share of 44.2\%). The share of those 
six countries in the EU milk production amounted to almost $70 \%$. However, the dairy farms in those countries differed significantly in terms of the production potential:

- The largest labour resources were characteristic of the British farms (2.61 AWU), and the smallest - the Dutch farms (1.73 AWU); the diversification was 1.5 -fold.

- The largest land resources (105.91 ha) were held by the British farms and the smallest - by the Polish farms (20.95 ha), the diversification was 5.1-fold. In addition, the farms used rented land to a varying extent. Their smallest share in utilised agricultural area in total was recorded by the Polish farms (25.9\%), and the largest - by the French farms $(90.0 \%)$.

- The highest value of total assets was characteristic of the Dutch farms and the lowest - of the Polish farms, the diversification was 14-fold. The share of fixed assets in total assets was the smallest on the Italian farms (67.0\%), and the largest - on the Dutch farms (91.0\%).

The intensity of livestock production organisation, specified by the number of dairy cows per 100 ha of UAA was the biggest in the Netherlands and Italy (166.5-167.8 LU), slightly smaller in Great Britain (115.2 LU), and relatively the lowest in Germany, Poland and France ( 60.6-77.4 LU). In terms of the production efficiency, the Italian farms are definitely outstanding, while the second position was usually occupied by the Polish farms. This is evidenced by:

- High profitability of production - on the Italian farms $32.6 \%$, and on the Polish farms $-25.6 \%$. When compared to other countries, the advantage was several times higher, the lowest profitability was recorded by the German farms $(5.5 \%)$ and French farms $(3.1 \%)$.

- Relatively low costs of manufacturing EUR 100 of production - on the Italian farms EUR 67, and on the Polish farms - EUR 75. In other countries, those costs were within the range of EUR 86-97.

- Low costs of obtaining EUR 100 income without subsidies - on the Italian farms EUR 206, and in the Polish farms - EUR 291. When compared to the farms from the Netherlands (EUR 720) and Great Britain (EUR 848), the advantage of the dairy farms from Italy and Poland was several times higher, and with respect to Germany (EUR 1,718$)$ and France $(3,163)$ - by z dozen or so times higher.

- High productivity of current inputs - on the Italian farms $191.3 \%$ and on the Polish farms $-179.2 \%$. In other countries, it was within the range of 177.6-143.5\% (respectively, in the Netherlands and Great Britain).

- Productivity of fixed capital input - it was the highest on the Italian farms - per PLN 1 of depreciation there were PLN 12.5 of revenues, the second place was occupied by the dairy farms from Great Britain - PLN 10.5. On the farms from other countries, the productivity ranged from PLN 7.3 to PLN 5.1 (on the Polish farms - PLN 6.4). 
The higher production efficiency on the Italian and Polish farms was largely determined by their low debt level and thus lower burden of costs. In the case of the Italian farms, liabilities financed $1.1 \%$ of the value of their assets, and on the Polish farms $-5.7 \%$, while as much as $42.7 \%$ on the French farms. This means that the French farms had the high financial risk related to pursuing production activity.

The Polish FADN data for 2014-2015 indicates the deterioration of the income situation of the dairy farms in 2015 , i.e. after the abolition of milk quotas. Farm income without subsidies decreased by $50.7 \%$, and with subsidies - by $15.4 \%$. Due to lower revenues (e.g., due to the fall in the milk price) the economic efficiency of production also deteriorated. In 2014, the farms keeping 16 cows with milk yield of about $5,300 \mathrm{~kg}$ and supported by subsidies, met the requirements of the parity farm, while in 2015 it was not fully possible.

It is estimated that the dairy farms in Poland made use of the opportunities created by the accession to the EU and strengthened their position on the European market. Their economic potential points to their further development. This however, mainly to large, prosperous entities whose income is independent from small fluctuations in milk prices. Investments made in recent years and technical and biological progress in the milk production have contributed to the growth production scale, and also to improved competitiveness on the European market.

The Polish dairy industry, in relation to all the EU-15 countries and most of the EU-N13 countries, maintains price-cost advantages (has dairy raw material cheaper by $10-15 \%$ than on average in the EU-15 and also lower labour costs). However, according to the researchers (Seremak-Bulge and Roman, 2016), in the nearest decade this may be insufficient. Therefore, what is necessary are the actions leading to the consolidation of processing, cooperation in the field of joint sales in foreign markets and strengthening the negotiating position in trade with networks. These actions are important as Poland will produce dairy products exceeding the internal needs and the export will remain the main stimulus for the economic situation on the milk market. 


\section{References}

Babuchowska, K., Marks-Bielska, R. (2011). Direct payments in the context of income of Polish farmers. Annals of Warsaw University of Life Sciences, Problems of Global Agriculture, vol. 11, b. 1, pp. 7-15.

Bieniasz, A., Gołaś, Z. (2008). Financial liquidity of farms in the European Union. J. Agribus. Rural Dev., 3(9), pp. 41-52.

Bocian, M., Cholewa, I., Tarasiuk, R. (2015). Standard output coefficients "2010" for the purposes of the Community Farm Typology. Warsaw: IAFE-NRI.

Coelli, T.J., Prasada Rao, D.S., O’Donnell, Ch.J., Battese, G.E. (2005). An introduction to efficiency and productivity analysis. Springer, pp. 88-90.

Czerwińska-Kayzer, D. (2002). Financing of investments in individual farms using preferential credit. Annals of Poznań Agricultural University, CCCXLIII, Ekon. 1, pp. 71-83. According to: Giselbrecht, P. (1991): Handbuch der Betriebsfinanzierung in der Landwirtschaft. Bayerische Raiffeisen Vertriebs- und Verlagsgesellschaft, München.

Czyżewski A., Kryszak, Ł. (2015). Price relationships in Polish agriculture and profitability of farms and households of farmers. Annals of Warsaw University of Life Sciences, Problems of Global Agriculture, vol. 15, b. 3, pp. 17-29.

Ćwiąkała-Małys, A., Nowak, W. (2001). Analysis of the financial situation of the enteprise in the market economy. Wrocław: Publishing House of the University of Wrocław.

Economic and agricultural encyclopaedia (1984). Warsaw: PWRiL.

European Commission (2015). EU Agricultural Outlook. Prospects for agricultural markets and income 2015-2025. Report Agriculture and Rural Development.

European Commission (2016). EU Dairy farms report based on 2013 FADN data. Brussels.

European Commission (2017). EU Milk Market Observatory. Retrieved from: https://ec.europa.eu/agriculture/ market-observatory/milk_en (access date: 06.04.2017).

Farm Accountancy Data Network (2017). Retrieved from: http://ec.europa.eu/agriculture/ rica (access date: 10.04.2017).

Floriańczyk, Z., Mańko, S., Osuch, D., Płonka, R. (2014). Standard results 2013 obtained by farms taking part in the Polish FADN. Part I. Standard results. Warsaw: IAFE-NRI

Floriańczyk, Z., Osuch, D., Płonka, R. (2015). Standard results 2014 obtained by farms taking part in the Polish FADN. Part I. Standard results. Warsaw: IAFE-NRI

Floriańczyk, Z., Osuch, D., Płonka, R. (2016). Standard results 2013 obtained by farms taking part in the Polish FADN. Part I. Standard results. Warsaw: IAFE-NRI

Goraj, L., Kulawik, J. (1995). Financial analysis of farms keeping agricultural accounts. Warsaw: IAFE-NRI.

Goraj, L., Mańko, S. (2004). Systems for monitoring the economic and production situation of farms. In: Agricultural Accounting. Warsaw: Difin.

GUS (2016). Prices in the national economy in 2015. Warsaw.

GUS (2016). Statistical Yearbook of Agriculture 2016. Warsaw.

Józwiak, W. (2003). Comparative advantages of Polish farms. Warsaw: IAFE-NRI.

Kosieradzka, A. (2012). Productivity management in the enterprise. Warsaw: Published by C.H. Beck.

Kulawik, J. (1995). Sources of capital in agriculture. Warsaw: IAFE-NRI. 
Lis, S. (ed.). (1999). Handbook of productivity. Warsaw: Publishing Agency PLACET.

Mańko, S. (2015). Economic analysis in the individual farm. Minikowo: Kujawsko-Pomorski Agricultural Advisory Centre.

Morse, P.W. (1994). Productivity Measurement in Canada. Europe Productivity Ideas - special issue Productivity Measurement Today, nr 1, pp. 16-19.

Nowak, E. (2008). Analysis of financial statements. Warsaw: PWE

Poczta, W., Średzińska, J., Mrówczyńska-Kamińska, A. (2009). Determinants of income of farms in the European Union by farming types. Annals of Warsaw University of Life Sciences, Economics and Organisation of Food Economy, no. 76, pp. 17-30.

Poczta, W., Średzińska, J., Pawlak, K. (2008). Financial situation of farms in the EU countries classified according to their production and economic results. Annals of Warsaw University of Life Sciences, Problems of Global Agriculture, vol. 4 (19 $\left.{ }^{\text {th }}\right)$, Warsaw: Published by Warsaw University of Life Sciences, pp. 379-387.

Milk Market. Status and prospects (2015). Market Analyses, no. 49. Warsaw: IAFE-NRI, AMA, MARD.

Seremak-Bulge, J., Roman, M. (2016). Situation in the global milk market and its impact on the Polish market and its development opportunities. In: S. Stańko (ed.), Situation in the global meat and dairy products markets and its impact on the domestic market and its development opportunities. Monographs of the Multi-Annual Programme 2015-2019, no. 31. Warsaw: IAFE-NRI

Von Keyserlingk, M.A.G., Rushen, J, de Passille, A.M., Weary, D.M. (2009). Invited review: The welfare of dairy cattle - key concepts and the role of science. Journal of Dairy Science, 92, pp. 4101-4111.

Woś, A. (ed.). (1996). Agribusiness. Vol. 2. Microeconomics. Warsaw: Published by Key Text.

Zegar, J.S. (2001). Conditions and determinants of the policy of shaping agricultural income. Warsaw: IAFE-NRI.

Zieliński, M. (2009). Farms of persons deriving income from more than one source. In: W. Józwiak (ed.), Economic situation, efficiency of the functioning and competitiveness of Polish farms of natural persons. Monographs of the Multi-Annual Programme 2005-2009, no. 132. Warsaw: IAFE-NRI

Ziętara, W. (1998). Economics and organisation of the agricultural enterprise. Warsaw: FAPA. 
ALDONA SKARŻYŃSKA

Instytut Ekonomiki Rolnictwa i Gospodarki Żywnościowej

- Państwowy Instytut Badawczy

Warszawa

\title{
WYNIKI GOSPODARSTW MLECZNYCH W POLSCE W PORÓWNANIU DO NAJWIĘKSZYCH PRODUCENTÓW MLEKA W UNII EUROPEJSKIEJ
}

\begin{abstract}
Abstrakt
W artykule przedstawiono wyniki ekonomiczne i efektywność produkcji $w$ gospodarstwach ukierunkowanych na produkcje mleka w sześciu krajach UE, które sq największymi jego producentami (tj. w Niemczech, Francji, Wielkiej Brytanii, Polsce, Holandii $i$ we Włoszech). Do analizy wykorzystano dane średnie FADN UE w latach 2010-2013. Ocenie poddano także wyniki gospodarstw polskich w latach 2014-2015, w badaniach wykorzystano dane gromadzone w systemie Polski FADN. Miarq oceny sytuacji ekonomicznej gospodarstw była wartość dodana netto i dochód z gospodarstwa. Ocene efektywności produkcji przeprowadzono, wykorzystujac wskaźnik produktywności nakładów obrotowych i kapitału trwałego, wskaźnik dochodowości produkcji oraz relacje kosztów ogółem do wartości produkcji i do dochodu z gospodarstwa bez dopłat. Analizie poddano także działalność inwestycyjna, stopień zadłużenia oraz majątek gospodarstw i jego wykorzystanie.

Pod względem efektywności produkcji wyróżniaja się gospodarstwa mleczne we Włoszech i w Polsce. Wskazuje na to wysoka dochodowość produkcji, relatywnie niskie koszty wytworzenia 100 euro produkcji i uzyskania 100 euro dochodu bez dopłat oraz wysoka produktywność nakładów obrotowych. Na wyniki wpływ miało niewielkie zadtużenie gospodarstw, a w efekcie mniejsze obciażenie kosztami. W przypadku gospodarstw włoskich zobowiazania finansowały 1,1\% wartości ich majątku, polskich - 5,7\%, podczas gdy $a \dot{z}$ 42,7\% we francuskich. Oznacza to, że gospodarstwa francuskie cechowato wysokie ryzyko finansowe zwiazane z prowadzeniem działalności produkcyjnej. Dane Polskiego FADN wskazuja na pogorszenie sytuacji dochodowej gospodarstw mlecznych w Polsce w roku 2015 (tj. po zniesieniu kwot mlecznych) w porównaniu do roku 2014. Dochód z gospodarstwa bez dopłat obniżyt się o 50,7\%, a liczony łacznie z dopłatami - o 15,4\%. Ze względu na niższe przychody (m.in. z powodu spadku ceny mleka) pogorszyła się także ekonomiczna efektywność produkcji.
\end{abstract}

Słowa kluczowe: produkcja mleka, gospodarstwa mleczne, dochód z gospodarstwa, dopłaty, efektywność produkcji, dochód parytetowy.

Accepted for print: 12.12.2017.

Unless stated otherwise all the materials on the website are available under the Creative Commons Attribution 3.0 Poland license. Some rights reserved to the Institute of Agricultural and Food Economics - National Research Institute.

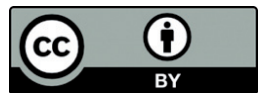

